\title{
Threats to multilateralism and the future of the EU-Canada Strategic Partnership: A view from Canada
}

\author{
ANTOINE RAYROUX \\ CÉRIUM (Montréal Centre for International Studies) \\ antoine.rayroux@gmail.com
}

\begin{abstract}
Current threats to the international multilateral order affect the EU and Canada to a fundamental degree. While this is an observation that transpires in most contributions to this special issue, this conclusion adds to the reflection by making three observations that we should bear in mind when trying to reflect on the future of the EU-Canada strategic partnership: first, the partnership will depend on the ability of both parties to build on the latter's recent institutionalization; second, it remains to be seen whether the US' retreat from multilateralism will prove surmountable for EU and Canada; and third, the partnership will only acquire true meaning if the EU and Canada succeed in working together on a series of crucial issues that require a multilateral effort - such as the environment and hybrid threats.
\end{abstract}

As international events remind us every week, the multilateral global order is shaken like it has never been before. This crisis of global multilateralism is a severe challenge for both Canada, the EU and its member states, to the extent that their respective foreign policy doctrines and strategies have traditionally relied on a strong presence and voice in multilateral institutions.

Thus, at a time where the US, Russia BICS, and other global powers show signs of retreat from multilateralism to various degrees, Canada and the EU appear as standard bearers for multilateral rules. It is therefore no surprise that all the articles gathered in this special issue take issue with how Canada and the EU cope with this changing reality and how it affects their bilateral strategic partnership.

What should we make of this "alliance for multilateralism" (Bendiek and Schenuit, 2019, in this Special Issue), and to what extent does the EU-Canada strategic partnership offer an opportune framework for both parties to try to preserve and further promote this multilateral order? While building on the findings of this Special Issue's different contributions, in this short concluding piece, I would like to offer a few brief reflections as seen from Canada. I argue that the future of the EU-Canada strategic partnership will depend on three elements: first, the ability to build on the recent institutionalization of the strategic partnership; second, whether the US's retreat from multilateralism will prove surmountable for both parties, especially for Canada; and third, the extent to which Canada and the EU will succeed in working together on a series of crucial issues that require a multilateral effort and have gained momentum recently - such as climate action and hybrid threats. Only then will we be able to consider that the partnership between the EU and Canada has acquired true strategic meaning. 


\section{Institutionalizing the Strategic Partnership}

While Canada and the EU have developed and maintained significant commercial, political and diplomatic relations since the 1960s, 2016 marked a significant step forward with the ratification of the CETA (Comprehensive Economic and Trade Agreement) and SPA (Strategic Partnership Agreement) between the two parties. Indeed, and as we are reminded in Amy Verdun's contribution to this Special Issue (Verdun, 2019), Canada has long viewed its relationship with the EU (and before that with the EC) as a pragmatic, mostly commercial one, instead of a truly strategic one (see also e.g. Potter, 1999; Croci and Tossutti, 2007). Not only is this due to the overwhelming focus of Canada's foreign policy on its Southern border (see following point), but also to a general lack of knowledge and understanding of the inner working of the EU. For Canadian political and economic elites, the EU has long appeared (and to a large extent, still does appear) as a complex institutional machinery that is difficult to understand and cope with from a policy-making perspective (Rayroux, 2018).

As such, the recent institutionalization of the strategic partnership is an important stepping-stone, because it considerably deepens the policy dialogue between Ottawa and Brussels - including by multiplying the direct contacts that occur between civil servants working in EU Directorate Generals (DGs) and ministerial cabinets in the federal government. Today, there are high-level policy dialogues that exist in 40 or so different areas, ranging from the SPA Joint Ministerial Committee meeting to a series of SPA sectoral dialogues and CETA specialised committees that meet at the level of policy directors, and which cover issues as diverse as environment, science and technology, sustainable trade, government procurement, and many more.

These meetings occur on an annual basis - usually in Ottawa, Brussels or via videoconferences. While it is of course not their primary function, they allow for Canadian policy elites to get a better grasp of the EU institutional system, which is probably less trivial than it may seem. Indeed, when it comes to the SPA and CETA implementation, on the Canadian side it is Global Affairs Canada that is tasked with policy dialogues in almost all sectors. On the EU's side however, the implementation is much less centralized and straightforward, since various DGs are responsible for different dialogues. For example, until the new European Commission came into power, policy dialogues related to sustainable development may have fallen under e.g. DG TRADE, GROW, ENVI, CLIMA, depending on what is at stake exactly. This easily creates confusion on the Canadian side, and may ultimately impact the effectiveness of the partnership. Therefore, the creation of direct contacts and networks between policy officers in charge of these dialogues on either side of the partnership is a welcome development.

\section{The ever-present shadow of the US}

One reason why the EU-Canada strategic partnership has indeed failed to be strategic for a long time has to do with the central position held by the US in the North Atlantic community. As the dominant Western power and shaper of the international multilateral order after World War II, the US have directly contributed to forging strong links between Europe and Canada. As a result though, both Canada and the EU have tended to treat one another only as an afterthought of their foreign policy strategy towards the US (Potter, 1999; Chaban, 2019, in this Special Issue). For example, the 2016 EU Global Strategy made no particular mention of Canada as a strategic partner on its own, rather 
only as part of the broader Atlantic Community (Rayroux, 2018). At the same time, from Canada's perspective relations with the EU have historically tended to warm up only when the bilateral partnership with the US was somehow suffering - usually for economic reasons (Johnston, 2013). This is true of history but is probably no different today.

As a consequence, the unilateral foreign policy shift that the US is currently operating will no doubt have an influence on the future of the EU-Canada strategic partnership. As several contributions to this Special Issue make clear, it is however not obvious whether this US retreat from multilateralism will mostly represent a constraint or an opportunity for Canadians and Europeans (for a Canadian perspective see also Payne, 2019).

On the one hand, Canadian and European policy-makers are overwhelmingly aware that everything must be done to incentivize the US to continue playing an active role in the multilateral order, since organizations like the WTO or NATO - to name only two would hardly be able to survive a US retreat. On the other hand, both Canada and the EU have no choice but to pursue this multilateral agenda - and to work together to that end - whatever happens to the "America first" unilateral movement over the medium to long term. Canada, as we know, is the exemplary case of a "middle power" in the world (Nossal, 2010), i.e. a power that sees itself as having a bridge-building role to play inside regional and global multilateral institutions, notably between the US and Europe. In that regard, Canada's significant involvement in e.g. NATO's enhanced Forward Presence Battle Group in Latvia (Operation REASSURANCE) should come as no surprise (Zyla, 2019, in this Special Issue). As far as the EU is concerned, it is itself an assemblage of mostly small and middle powers that must work together towards achieving their common goals and promoting a rules-based international order.

As a consequence, and notwithstanding the fact that foreign policy priorities in Canada may change on the margins, depending on whether Liberals or Conservatives are in power (the former favour traditionally a more liberal internationalist posture, whereas the latter are more focus on a continental alignments with the US), in the long term we should expect Canada and the EU to align closely together to defend multilateralism (Chaban, 2019, in this Special Issue).

\section{Strategic Partnership and multilateralism in action: environment and security}

Looking at policy issues where the EU-Canada strategic partnership could make progress in the years to come, climate action and the fight against hybrid threats seem to be two promising areas that stand out, for various reasons. Climate action is a cornerstone of the newly elected European Commission's policy agenda under its European Green Deal; it is also a central element of Prime Minister Justin Trudeau's reelected government. As regards hybrid security threats, it is not as high on the policy agenda, but it is probably one of the fields where the EU-Canada policy dialogue has been the most active recently.

The rationale for an EU-Canada joint climate action is already addressed by Bendiek and Schenuit (2019, in this Special Issue) and will therefore not be detailed here. However, a few points that have to do with domestic politics in Canada deserve to be mentioned, since they could impede the partnership in the near future. For example, one area of contention mentioned by Bendiek and Schenuit (209) is the extent to which government 
subsidies for the fossil fuel industries should be cut. When it comes to Canada, the oil and gas industry accounts for roughly $7 \%$ of the country's GDP - far more than the EU's average - which makes such a move challenging. Also, the 2019 Canadian general election has been characterized by both the election of a liberal minority government campaigning on the environment, and a deep geographical and electoral divide in the country, where energy-producing provinces have voted very largely in favour of the Conservatives, which sit in the opposition. As a result, Justin Trudeau's climate action plans may well face a political reality-check that will make any bold policies difficult to implement (Hébert, 2019).

In addition, let us not forget that both the EU and Canada are characterized by a complex multilevel governance system that limits their ability to take action. In Canada, policy competences in the environmental sector are shared with the provincial and municipal levels (e.g. waste management policy in case of the latter). In the EU, the Commission's Green Deal plans will also have to face the opposition of several member states in the Council, whose economy remains heavily dependent on fossil fuels (Leonard, 2019).

As far as hybrid threats to security go, the EU, European member states and Canada have been involved in a series of initiatives over the past decade, either on their own or in the context of NATO and EU/NATO cooperation. For example, the European Centre of Excellence for Countering Hybrid Threats was established in 2017 in Helsinki, following a joint EU/NATO Declaration that was endorsed by both organizations' decision-making bodies. It complements the activities undertaken by NATO's Cooperative Cyber Defence Centre for Excellence, which was created 10 years earlier in Tallinn. Therefore, it is not surprising that the fight against hybrid and cybersecurity threats has emerged as an area where the strategic partnership between the EU and Canada has evolved quite rapidly.

On the EU's side, many specific projects undertaken in the framework of PESCO are currently focusing on cybersecurity, such as the Cyber Rapid Response Teams - teams of experts that are on standby and ready to assist member states that are victims of cyber attacks. The mechanism somehow echoes an initiative that was launched by Canada during the annual G7 summit that it hosted in 2018: the Rapid Response Mechanism. With a coordination unit currently hosted at Global Affairs Canada, the Rapid Response Mechanism's goal is to provide an information-sharing platform for G7 members, which offers analysis, intelligence and potential solutions against foreign interferences in democratic processes. While this mechanism is not focused on hybrid threats only, in reality most of these threats are of a cyber nature at the moment, and they affect the EU and Canada in a very similar way (Hanouna et al., 2019, in this Special Issue). Therefore, and as advanced by Leuprecht and Hamilton in their article (Leuprecht and Hamilton, 2019, in this Special Issue), the EU's ability and willingness to bring third countries such as Canada on board PESCO projects will be crucial to feed the strategic partnership at the bilateral level in a policy area that is deemed crucial for both parties.

Security and the environment are only two examples of policy areas that require a multilateral approach to be addressed effectively. They also demonstrate that the EUCanada partnership is ripe for being more than a trade and economic relationship. To conclude, let me just stress that none of the three elements addressed in this brief conclusion should be seen as a definitive assessment of where the EU-Canada strategic partnership is heading. They are mostly open questions that I believe are worth keeping 
in mind when trying to make sense of future evolutions: will the institutionalization of the strategic partnership succeed in stepping up the policy dialogue between the EU and Canada? Will the EU and Canada be able to work together despite waning support coming from their US ally? Will some of the major global challenges of today and tomorrow in the fields of security or the environment be tackled effectively by the EU and Canada together? Hopefully the many observations contained in this special issue will prove useful to provide us with a first series of answers to these questions.

\section{References}

Bendiek, Annegret and Schenuit, Felix (2019) "Alliance for multilateralism: EU-Canada strategic partnership, Australian and New Zealand Journal of European Studies 11(3).

Chaban, Natalia (2019) "Perceptions, expectations, motivations: Evolution of Canadian views on the EU”, Australian and New Zealand Journal of European Studies 11(3).

Croci, Osvaldo, and Tossutti, Livianna (2007) "That Elusive Object of Desire: Canadian Perceptions of the European Union", European Foreign Affairs Review 12(3): 287-310.

Hébert, Chantal (2019) "Climate Change is the Biggest Threat to Trudeau's Minority Government,” The Toronto Star, December 1, 2019.

Hurrelmann, Achim (2020) "Canada's Two Europes: Brexit and the Prospect of Competing Transatlantic Relationships", in Chaban, Natalia, Niemann, Arne and Speyer, Johanna (eds.), External Perceptions of the EU after Brexit and their Impact on Foreign Policy, London: Routledge.

Johnston, Richard (2013) "Alignment, Realignment, and Dealignment in Canada: The View From Above", Canadian Journal of Political Science / Revue canadienne de science politique 46(2): 245-271.

Leonard, Mark (2019) “The Green Deal Will Make or Break Europe,” Project Syndicate, December 13, 2019. https://www.project-syndicate.org/commentary/european-greendeal-von-der-leyen-by-mark-leonard-2019-12 [accessed: 20 January 2020]

Leuprecht, Christian and Hamilton, Rhianna (2019) "New opportunities in Common Security and Defence Policy: Joining PESCO”, Australian and New Zealand Journal of European Studies, 11(3).

Nossal, Kim Richard (2010) “'Middlepowerhood' and 'Middlepowermanship' in Canadian Foreign Policy," in Hynek, Nik and Bosold, David (Eds.), Canada's Foreign and Security Policy: Soft and Hard Strategies of a Middle Power, Toronto: University of Toronto Press.

Hanouna, Simo, Neu, Omer, Pardo, Sharon, Tsur, Oren, Zahavi, Hila (2019) "Sharp power in social media: Patterns from datasets across electoral campaigns", Australian and New Zealand Journal of European Studies, 11(3).

Payne, Roger (2019) “America First” and U.S.-Canadian Relations," in Carment, David and Sands, Christopher (eds.) Canada-US Relations. Canada and International Affairs. London: Palgrave Macmillan.

Potter, Evan (1999) Transatlantic Partners. Canadian Approaches to the European Union, Montréal, Kingston: McGill, Queen's University Press. 
Rayroux, Antoine (2018) “The EU's Reputation in Canada: Still a Shallow Strategic

Partnership?", in Chaban, Natalia and Holland, Martin (Eds.), Shaping the EU's Global Strategy: Partners and Perceptions, Basingstoke: Palgrave Macmillan.

Verdun, Amy (2019) "EU-Canada Strategic Partnership: Ups and Downs", Australian and New Zealand Journal of European Studies, 11(3). 